\title{
Pendampingan Pembuatan dan Pemanfaatan Media Permainan Balap Egrang di SD 4 Karangbener Kudus
}

\author{
Himmatul Ulya ${ }^{1}$, Sekar Dwi Ardianti ${ }^{2}$ \\ ${ }^{1}$ Program Studi Pendidikan Matematika, Universitas Muria Kudus \\ ${ }^{2}$ Program Studi Pendidikan Guru Sekolah Dasar, Universitas Muria Kudus \\ Email corresponding author: himmatul.ulya@umk.ac.id
}

\begin{abstract}
Abstrak: Pemanfaatan media permainan berbasis lingkungan dan keunggulan lokal di dalam pembelajaran SD 4 Karangbener belum dilakukan. Hal ini disebabkan oleh kurangnya pengetahuan dan keterampilan guru dalam mengembangkan dan menggunakan media permainan. Pembelajaran yang tidak menggunakan media menyebabkan dominasi guru yang tinggi dalam pembelajaran. Peserta didik tidak diberikan kesempatan aktif sehingga aktivitas belajarnya rendah. Balap Egrang merupakan salah satu permaianan berbasis budaya dan memanfaatkan lingkungan yang dapat dimanfaatkan guru untuk pembelajaran. Tujuan kegiatan pengabdian ini yaitu memberikan pendampingan terhadap guru untuk mendesain, membuat, dan menggunakan media permainan Balap Egrang. Metode pelaksanaan kegiatan pendampingan ini memakai pendekatan participant active learning, dimana peserta pendampingan berperan aktif selama pelaksanaan kegiatan. Hasil yang dicapai dalam pengabdian ini yaitu guru-guru di SD 4 Karangbener: (1) memperoleh pengetahuan tentang media permainan Balap Egrang; (2) dapat membuat media permainan Balap Egrang; (3) menggunakan media permainan Balap Egrang; dan (4) terampil dalam mengimplementasikan pembelajaran yang memanfaatkan media permainan Balap Egrang.
\end{abstract}

Kata kunci: balap egrang, keunggulan lokal, lingkungan, media permainan

\section{PENDAHULUAN}

Pembelajaran di sekolah dasar dewasa ini masih belum sesuai dengan prinsip pembelajaran di kurikulum 2013, yaitu pembelajaran yang berpusat pada peserta didik. Hal ini diperkuat hasil penelitian yang menunjukkan bahwa pembelajaran matematika selama ini didominasi oleh guru (Ulya \& Rahayu, 2017b). Hal ini menyebabkan peserta didik tidak memiliki kemampuan matematis yang tinggi karena hanya mengikuti penyelesaian masalah secara mekanik seperti yang dijelaskan oleh guru (Rahayu, Ulya, Kartono, Isnarto, \& Kurniasih, 2018). Pembelajaran dengan berpusat pada peserta didik akan memberikan kesempatan dan fasilitas kepada peserta didik untuk menggali dan mengembangkan pengetahuan dan kemampuannya sendiri sehingga peserta didik mendapatkan ilmu yang lebih dalam dan bermakna (Antika, 2014).

Di dalam kurikulum 2013 sebagai pembelajaran tematik terpadu seyogyanya guru dituntut untuk dapat menciptakan pembelajaran yang bermakna dan menyenangkan. Keterpaduan dalam pembelajaran tematik terpadu dimaksudkan agar pembelajaran lebih bermakna, efektif, dan efisien (Ardianti, 2015). Selain pembelajaran berjalan dengan efektif dan efisien perlu juga diperhatikan karakteristik peserta didik sekolah dasar. Peserta didik sekolah dasar masih suka dengan kegiatan bermain, sehingga diperlukan kegiatan yang menyenangkan dalam pembelajarannya. Kegiatan pembelajaran yang dikemas dalam nuansa hiburan diharapkan dapat memberikan suasana belajar tanpa tekanan bagi siswa sehingga dapat memberikan pengaruh pada peningkatan prestasi belajar siswa (Ardianti, Wanabuliandari, \& Rahardjo, 2019). Guru hendaknya kreatif dalam mengembangkan media pembelajaran atau permainan yang efektif agar dapat digunakan untuk mencapai tujuan 
pembelajaran (Dananjaya, 2011). Pemanfaatan media pembelajaran atau permainan dalam pembelajaran dapat memberikan nilai dan manfaat bagi peserta didik, yaitu memvisualisasikan konsep-konsep atau materi yang abstrak menjadi konkret, memberikan kesempatan peserta didik untuk saling berinteraksi, dan menumbuhkan minat dan motivasi belajar peserta didik (Hernawan, Zaman, \& Riyana, 2007). Media pembelajaran juga dapat digunakan untuk memperjelas materi yang dipelajari sehingga akan mudah dipahami oleh peserta didik (Mulyani, 2013).

Berdasarkan informasi yang didapatkan dari beberapa guru dan peserta didik di SD 4 Karangbener, diperoleh bahwa pembelajaran yang dilakukan di SD 4 Karangbener belum memanfaatkan media permainan. Hal ini disebabkan oleh ketersediaan media permainan yang sangat minim. Minimnya ketersediaan media permainan di SD tersebut karena kurangnya pengetahuan dan keterampilan guru dalam mengembangkan dan menggunakan media permainan. Selain itu, guru memiliki anggapan bahwa mengembangkan media pembelajaran atau permainan membutuhkan bahan dengan biaya yang mahal. Sementara itu media pembelajaran atau permainan dapat dikembangkan secara sederhana. Guru dapat menggunakan bahan-bahan yang berasal dari lingkungan sekitar yang murah dan mudah didapat. Media pembelajaran atau permainan yang dikembangkan guru juga dapat mengacu pada keunggulan lokal daerah agar peserta didik mengenal budaya dan dapat melestarikan keunggulan lokal daerahnya. Pembelajaran dengan memanfaatkan lingkungan sekitar dan keunggulan daerah dapat memberikan dampak positif terhadap hasil belajar dan peningkatan karakter cinta tanah air (Ardianti, Wanabuliandari, \& M, 2019). Pembelajaran di SD 4 Karangbener belum menggunakan cara belajar yang bervariasi. Hal ini menyebabkan peserta didik merasa bosan dan ketika pembelajaran berlangsung peserta didik lebih suka bermain.

Permasalahan pembelajaran di SD 4 Karangbener dapat diatasi dengan meningkatkan keterampilan guru dalam mengembangkan dan menggunakan media permainan. Salah satu media permainan yang dapat dikembangkan guru yaitu media Balap Egrang. Media Balap Egrang merupakan permainan tradisional yang mudah dikembangkan. Balap Egrang berasal dari tempurung (batok) kelapa. Penggunaan batok kelapa merupakan salah satu cara untuk memanfaatkan lingkungan (bahan daur ulang) sebagai sumber belajar. Melalui pemanfaatan lingkungan sebagai sumber belajar khususnya lingkungan alam, peserta didik diharapkan ikut berperan dalam menjaga dan melestarikan lingkungan sekitar ('Ulum, 2014).

Penggunaan permainan dalam pembelajaran diharapkan dapat menumbuhkan minat peserta didik untuk belajar. Selain itu, aktivitas dan sikap positif untuk belajar peserta didik juga akan meningkat karena peserta didik dilibatkan di dalam pembelajaran (Ulya \& Rahayu, 2017a). Minat dan aktivitas belajar yang semakin meningkat dapat memberikan indikasi bahwa kualitas pembelajaran semakin baik sehingga akan mempengaruhi hasil belajar peserta didik. Melalui permainan Balap Egrang yang merupakan salah satu permainan tradisional ini peserta didik akan belajar secara kontekstual sekaligus mengenal budaya yang harus dilestarikan. Dengan demikian, peserta didik akan belajar secara bermakna dan menyenangkan sehingga berdampak baik terhadap hasil belajarnya.

Berdasarkan permasalahan yang dihadapi mitra, maka diperlukan solusi guna mengatasi persoalan pembelajaran di SD 4 Karangbener Kudus. Solusi yang dilakukan yaitu memberikan pendampingan terhadap guru dalam mengembangkan dan menggunakan media yang berasal dari lingkungan dan mengandung keunggulan lokal. Guru akan didampingi untuk berlatih merancang, membuat, serta menggunakan media Balap Egrang. Dengan 
meningkatkan keterampilan guru melalui pendampingan ini, diharapkan guru semakin profesional dan kualitas pembelajaran menjadi lebih baik sehingga akan berdampak baik pada hasil belajar peserta didik.

\section{METODE PELAKSANAAN}

\subsection{Waktu dan Lokasi Mitra}

Kegiatan pendampingan pembuatan dan pemanfaatan media permainan Balap Egrang sebagai hibah Program Kemitraan Masyarakat dilaksanakan pada bulan Maret sampai dengan September tahun 2019. Kegiatan pendampingan dilaksanakan di SD 4 Karangbener. SD ini berlokasi di Desa Karangbener, Kecamatan Bae, Kabupaten Kudus. Sasaran kegiatan pengabdian ini yaitu guru-guru SD 4 Karangbener.

\subsection{Metode dan Pendekatan}

Pelaksanaan kegiatan pendampingan ini memakai pendekatan participant active learning. Di dalam metode ini peserta pendampingan berperan aktif selama pelaksanaan kegiatan. Melalui partisipasi aktif dari perserta, maka kegiatan pendampingan menjadi interaktif. Tim pengabdian dan guru SD 4 Karangbener sebagai mitra dapat bertukar pengetahuan dan pengalaman guna mendapatkan ilmu baru yang dapat diterapkan dalam pembelajaran di sekolah dasar. Metode yang digunakan dalam proses pendampingan ini yaitu ceramah, tanya jawab, diskusi, simulasi, dan praktik.

\section{HASIL DAN PEMBAHASAN}

\subsection{Tahap Observasi dan Perizinan}

Tahap observasi dilaksanakan untuk mengidentifikasi permasalahan yang dihadapi oleh mitra di SD 4 Karangbener. Observasi dilakukan melalui pengamatan di lapangan dan wawancara. Setelah memperoleh permasalahan mitra, tim pengabdian melakukan perizinan untuk mengadakan kegiatan pengabdian guna memberikan solusi dari permasalahan.

\subsection{Tahap Perencanaan}

Tahap perencanaan merupakan tahap persiapan untuk melakukan pendampingan. Tahap ini meliputi diskusi mengenai jenis media permainan yang akan digunakan untuk pendampingan. Media permainan yang akan digunakan untuk pendampingan yaitu Balap Egrang. Alasannya yaitu Balap Egrang merupakan salah satu permainan berbasis keunggulan lokal dan bahan yang digunakan untuk membuatnya berasal dari lingkungan, murah, dan mudah didapat. Dalam membuat Balap Egrang dapat memanfaatkan tempurung kelapa yang sudah tidak digunakan dan tali sebagai penautnya. Setelah menentukan jenis media, tim pengabdian menyusun buku petunjuk atau buku panduan untuk membuat dan menggunakan media permainan Balap Egrang. Selanjutnya, untuk melakukan pendampingan tim pengabdian menyiapkan peralatan dan bahan-bahan sesuai keperluan membuat media. Berikut ini salah satu dokumentasi pada tahap perencanaan. 


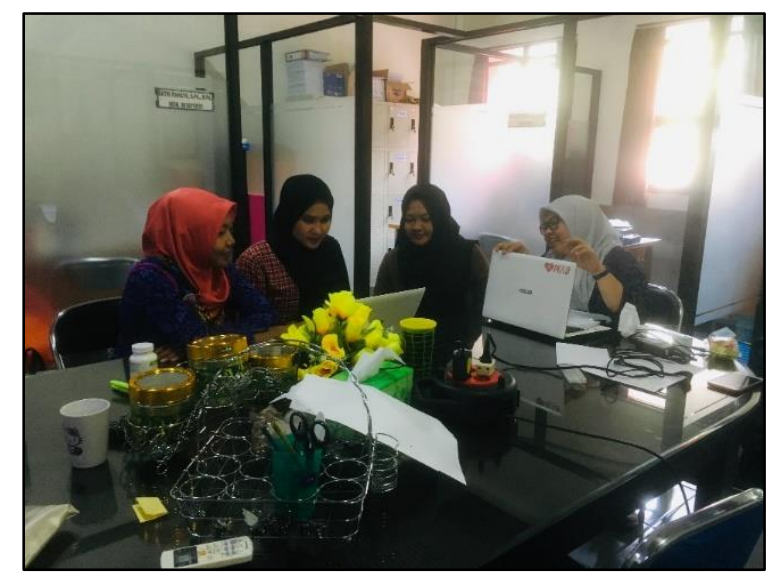

\subsection{Tahap Pelaksanaan}

Gambar 1. Kegiatan Tahap Perencanaan

Tahap pelaksanaan pendampingan dilakukan serangkaian kegiatan sebagai berikut.

\section{Tahap Penyampaian Materi}

Materi yang disampaikan pada tahap penyampaian materi yaitu (1) bahan-bahan bersumber dari lingkungan untuk media pembelajaran atau permainan; (2) macam-macam keunggulan lokal dan pengintegrasian keunggulan lokal dalam pembelajaran; dan (3) petunjuk pendesainan, pembuatan, dan penggunaan media Balap Egrang. Kegiatan pada tahap penyampaian materi disajikan pada Gambar 2.

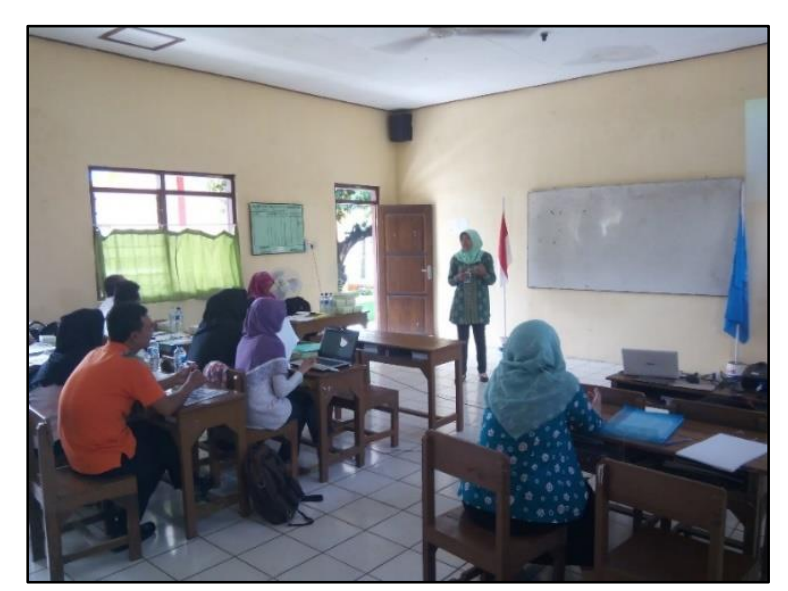

Gambar 1. Penyampaian Materi Pendampingan

Media Balap Egrang merupakan salah satu permainan tradisional yang mudah dimainkan oleh peserta didik. Media tersebut berbasis keunggulan lokal dan lingkungan. Selain peserta didik dapat belajar dan bermain, media ini dapat digunakan sebagai media untuk mengenalkan budaya-budaya kepada peserta didik sehingga peserta didik dapat ikut melestarikan budaya suatu daerah. Balap Egrang berasal dari 2 tempurung (batok) kelapa yang bagian tengahnya dilubangi untuk diberikan tali penaut. 


\section{Tahap Pembuatan}

Tahap pendampingan untuk membuat dan menggunakan media permainan dilaksanakan pada hari Rabu, tanggal 15 Mei 2019. Dalam kegiatan pendampingan guru sebagai peserta pendampingan sangat mengapresiasi kegiatan ini. Peserta sangat interaktif dan bersemangat mengikuti kegiatan pendampingan. Pembuatan media permainan Balap Egrang sebagai media permainan berbasis lingkungan dan keunggulan lokal merupakan ilmu dan pengalaman baru bagi guru.

Cara untuk membuat media permainan Balap Egrang yaitu membuat egrang dan puzzle terlebih dahulu. Langkah-langkah untu membuat egrang meliputi: (1) menyiapkan kelapa yang akan digunakan; (2) membelah kelapa menjadi 2 bagian; (3) mengambil seluruh daging kelapa yang bewarna putih sampai bersih; (4) menjemur batok selama 1 sampai 2 jam hingga kering; (5) setelah batok kering, meratakan bagian pinggir batok dengan menggunakan gerinda; (6) menghaluskan bagian luar batok dengan menggunakan gerinda; (7) mengamplas bagian dalam batok sampai halus; (8) melakukan pewarnaan pada bagian luar batok hingga bagian dalam batok dengan merata; (9) mengeringkan cat batok dalam beberapa jam; (10) setelah cat kering, melubangi bagian tengah batok; (11) memotong tali menjadi ukuran 2 meter; (12) mengaitkan ujung-ujung tali pada batok-batok yang telah dilubangi.

Setelah membuat egrang, guru didampingi untuk membuat puzzle. Langkah-langkah pembuatan puzzle meliputi: (1) menyiapkan gambar keunggulan lokal yang telah dicetak pada kertas stiker ukuran A4; (2) menempelkan stiker pada papan puzzle yang terbuat dari kardus/kayu; dan (3) momotong stiker sesuai dengan pola yang ada di puzzle. Puzzle ini digunakan untuk turnamen dalam permainan Balap Egrang. Kelompok yang tercepat dalam menyusun puzzle menjadi pemenang. Balap Egrang dapat digunakan sebagai media permainan berbagai mata pelajaran/muatan.

\section{Tahap Simulasi Penggunaan}

Tahap simulasi penggunaan merupakan tahap dimana guru mempraktikkan pembelajaran yang di dalamnya memanfaatkan media permainan Balap Egrang. Tahap ini dilakukan pada hari Senin, tanggal 16 September 2019. Salah satu guru mempraktikkan pembelajaran IPA menggunakan media permainan Balap Egrang. Peserta didik sangat antusias dan tertarik dalam pembelajaran karena di dalamnya terdapat permainan yang menyenangkan.

Cara memainkan permainan Balap Egrang sangat mudah. Peserta didik dapat meletakkan masing-masing kakinya di atas masing-masing batok kelapa. Masing-masing kaki diangkat secara bergantian seperti ketika berjalan. Kaki yang tidak diangkat bertumpu pada batok kelapa yang menempel di lantai. Peserta didik dapat memegang tali untuk menjaga keseimbangan berjalan/berlari.

Pada tahap Simulasi Penggunaan mula-mula guru membagi kelas menjadi beberapa kelompok dengan jumlah anggota 4-5 peserta didik. Salah satu peserta didik dalam kelompok secara bergantian (estafet) bertugas mengambil potongan puzzle menggunakan egrang, sedangkan anggota yang lain bertugas menyusun puzzle. Untuk mendapatkan potongan puzzle, peserta didik harus menjawab pertanyaan yang telah disiapkan oleh guru. Apabila peserta didik tidak dapat menjawab, guru memberikan pertanyaan lain sampai peserta didik dapat menjawab pertanyaan. Tahap simulasi permainan Balap Egrang dalam kegiatan pendampingan disajikan pada Gambar 3, 4, dan 5. 


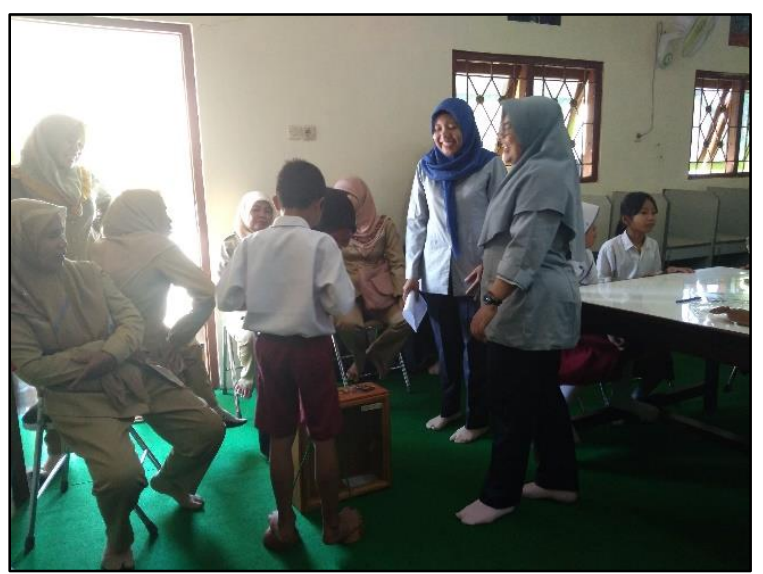

Gambar 3. Estafet Peserta Didik dalam Permainan Balap Egrang

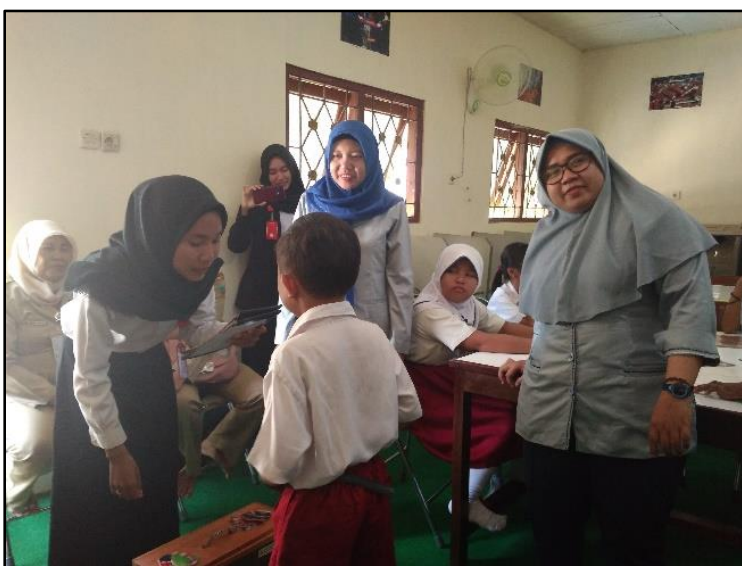

Gambar 4. Menjawab Pertanyaan dalam Permainan Balap Egrang

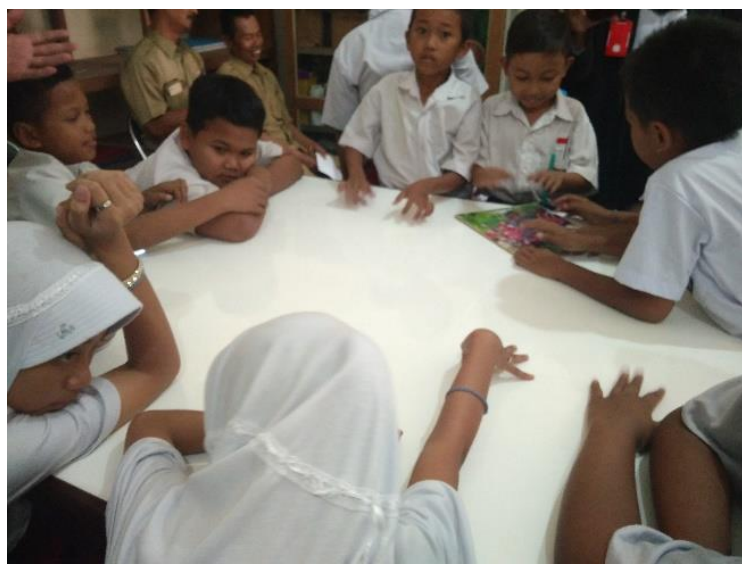

Gambar 5. Penyusunan Puzzle dalam Permainan Balap Egrang

Dengan permainan Balap Egrang, peserta didik diarahkan untuk mempelajari konsep dan memecahkan masalah, sehingga peserta didik dibiasakan untuk belajar mandiri dan menghadapi masalah untuk dipecahkan mandiri maupun kelompok. Hal ini dilakukan agar peserta didik terlibat langsung di dalam pembelajaran sehingga aktivitas belajarnya meningkat. 


\subsection{Tahap Evaluasi}

Tahap evaluasi dalam kegiatan pendampingan ini meliputi evaluasi hasil pendampingan pembuatan dan pemanfaatan media permainan Balap Egrang dalam pembelajaran. Setelah evaluasi dilakukan diperoleh hasil bahwa sebanyak 93\% guru telah mempunyai pengetahuan dan keterampilan untuk membuat dan memanfaatkan media permainan Balap Egrang dalam pembelajaran. Dari aspek aktivitas belajar, $80 \%$ peserta didik sudah berpartisipasi aktif dan semua peserta didik telah terlibat dalam pembelajaran. Berdasarkan informasi dari guru yang mengimplementasikan media permainan Balap Egrang dalam pembelajaran menunjukkan bahwa hasil belajar peserta didik juga meningkat.

\section{SIMPULAN}

Hasil yang telah dicapai dalam kegiatan pendampingan ini adalah sebagai berikut.

1) Guru-guru di SD 4 Karangbener memperoleh pengetahuan tentang media permainan Balap Egrang dalam pembelajaran.

2) Guru-guru di SD 4 Karangbener dapat membuat media permainan Balap Egrang.

3) Guru-guru di SD 4 Karangbener dapat menggunakan media permainan Balap Egrang.

4) Guru-guru di SD 4 Karangbener terampil dalam mengimplementasikan pembelajaran yang memanfaatkan media permainan Balap Egrang.

\section{UCAPAN TERIMA KASIH}

Ucapan terima kasih disampaikan kepada Direktorat Riset dan Pengabdian Masyarakat Direktorat Jenderal Riset dan Pengembangan Kementerian Riset, Teknologi, dan Pendidikan Tinggi yang telah mendanai kegiatan pengabdian melalui hibah Program Kemitraan Masyarakat tahun 2019. Selain itu, ucapan terima kasih juga ditujukan kepada mitra, yaitu kepala sekolah, seluruh guru, peserta didik SD 4 Karangbener, dan seluruh pihak yang ikut terlibat dalam kegiatan pengabdian ini.

\section{DAFTAR PUSTAKA}

'Ulum, I. (2014). Pemanfaatan Lingkungan Sebagai Sumber Belajar Anak. Jurnal Pendidikan Anak, 3(2), 518-523.

Antika, R. R. (2014). Proses Pembelajaran Berbasis Student Centered Learning (Studi Deskriptif di Sekolah Menengah Pertama Islam Baitul 'Izzah, Nganjuk). Jurnal BioKultur, III(1), 251-263.

Ardianti, S. D. (2015). Pengaruh Modul Tematik Inquiry-Discovery Terhadap Hasil Belajar Siswa Materi Metabolisme Pembentuk Bioenergi. Jurnal Refleksi Edukatika, 5(2), 1-6.

Ardianti, S. D., Wanabuliandari, S., \& M, K. (2019). Implementasi Pembelajaran Berbasis Ethno-edutainment untuk Meningkatkan Karakter Cinta Tanah Air Siswa Sekolah Dasar. Jurnal Refleksi Edukatika, 9(2), 204-209.

Ardianti, S. D., Wanabuliandari, S., \& Rahardjo, S. (2019). The Implementation Of E-JAS Science Edutainment To Improve Elementary School Student's Conceptual Understanding. Unnes Science Education Journal, 8(1), 1-6. 
Dananjaya, U. (2011). Media Pembelajaran Aktif(Nuansa). Bandung.

Hernawan, A. H., Zaman, B., \& Riyana, C. (2007). Media Pembelajaran Sekolah Dasar. Bandung: UPI Press.

Mulyani, S. (2013). Pembelajaran Matematika dengan Alat Peraga Papan Berpasangan. EJurnal Dinas Pendidikan Kota Surabaya, 5, 1-11.

Rahayu, R., Ulya, H., Kartono, Isnarto, \& Kurniasih, N. (2018). Collaborative Assessment Using QR-Code on Ethnomathematics Learning for Pre-Service Teacher. International Journal of Engineering \& Technology, 7(2.13), 413-417.

Ulya, H., \& Rahayu, R. (2017a). Increasing Primary School Students' Attitude Toward Mathematics Through The Implementation Of Treffingerlearning Using Dakon Game. International Conference on Education Universitas Muhammadiyah Purworejo, 1-7.

Ulya, H., \& Rahayu, R. (2017b). Pembelajaran Treffinger Berbantuan Permainan Tradisional Congklak Untuk Meningkatkan Kemampuan Komunikasi Matematis. Jurnal Aksioma, $6(1), 48-55$. 